ECONOMICS

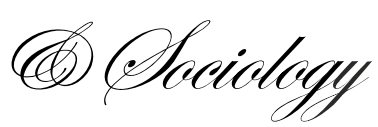

\author{
Helena Tendera-Właszczuk, \\ European Economic Integration \\ Department, \\ Faculty of Economics and \\ International Relations, \\ Cracow University of Economic, \\ Cracow, Poland, \\ E-mail:tendera@uek.krakow.pl
}

Michał Szymański,

Faculty of Economics and

International Relations,

Cracow University of Economic,

Cracow, Poland,

E-mail:

michalsyymanski1990@interia.pl

Received: March, 2015

1st Revision: June, 2015

Accepted: July, 2015

DOI: $10.14254 / 2071-$

789X.2015/8-2/10
Tendera-Właszczuk, H., Szymański, M. (2015), Implementation of the Welfare

State in the Visegrád Countries, Economics and Sociology, Vol. 8, No 2, pp. 126-142. DOI: $10.14254 / 2071-789 X .2015 / 8-2 / 10$

\section{IMPLEMENTATION OF THE WELFARE STATE IN THE VISEGRÁD COUNTRIES}

\begin{abstract}
This paper aims to match the Visegrád countries which joined the European Union in 2004 and are usually analysed as a separate group of their own (often referred to as the "catching-up countries") with the welfare models functioning in Western Europe. The empirical part includes an analysis of the practical functioning of the welfare state in the Visegrád countries against the broader background of the EU-15. The working hypothesis is that the models differ in terms of the effectiveness and justice of embraced solutions, as well as the influence of public spending on the quality of life and reduction of poverty. Our analysis shows that one can classify Czech Republic as a country of the Nordic model, Hungary and Slovakia as Continental and Poland as Mediterranean. The Nordic system performs the best among all the welfare state models in terms of the principal assessment criteria that include the labour market situation, as well as the reduction of poverty and social inequalities. However, their policies have not been very cost-effective; public spending exceeds $30 \%$ of the GDP, and the global crisis has increased it even further. The example of Anglo-Saxon Ireland shows that public expenditure can be used more effectively to fight poverty; Ireland has managed to reduce poverty by almost as much as Sweden, Finland, or Denmark, but at a much lower cost.

In the analysis, the Visegrád countries, the Czech Republic (the Nordic model) and Slovakia (the continental model) in particular, achieve satisfactory results across all indicators.
\end{abstract}

JEL Classification: E24, I31, $\mathrm{I} 38, \mathrm{~J} 21$
Keywords: welfare states, the European Social Model (ESM), Visegrád countries, labour market, reduction of poverty.

\title{
Introduction
}

In the aftermath of the Second World War, the countries of Western Europe have adopted a special socio-economic model, known today as the welfare state or the European Social Model (ESM). The model can be considered a specific example of social policy implemented on European soil (hereinafter, the terms 'social policy' and the 'European social model' will be used interchangeably). However, it is worth noting that despite many similarities, the details of its implementation have varied from one state to another (see 
Strielkowski et al., 2014; or Strielkowski and Čábelková, 2015). The Visegrád countries, which joined the European Union in 2004, have usually been analysed as a separate group of their own, referred to as the "catching-up countries". The purpose of this article is to match them with the welfare models functioning in Western Europe. The research part includes an analysis of the practical functioning of the welfare state in the Visegrád countries against the broader background of the EU-15. The hypothesis is that the models differ in terms of the effectiveness and justice of embraced solutions, as well as the influence of public spending on the quality of life and reduction of poverty.

\section{Basic concepts and definitions}

The European Social Model (ESM) is not easy to define, as the EU member states have adopted many different variants of the model within their national frameworks. This is mainly due to the difference in traditions, cultures, and experiences, as well as the level of economic development. However, there also exist certain similarities between the different national solutions, and, consequently, it is possible to propose a general and coherent definition of ESM by enumerating its most important features (Borowiec, 2011).

The Treaty on the functioning of the European Union (TFEU) emphasizes that:

- "In all its activities, the Union shall aim to eliminate inequalities, and to promote equality, between men and women" (art. 8);

- art. 9: "In defining and implementing its policies and activities, the Union shall take into account requirements linked to the promotion of a high level of employment, the guarantee of adequate social protection, the fight against social exclusion, and a high level of education, training and protection of human health".

Other important articles related to the ESM are articles 151-161 of the TFEU, which form part of the chapter on the EU's social policy. The latter outlines the goals of European social policy, specific areas of activity, and the competences of individual European institutions and member states. Provisions concerning these issues can also be found in the Basic Rights Charter.

According to the British sociologist Anthony Giddens, four general features of the ESM can be distinguished (Giddens, 2006):

- relatively high taxation and wide scope of state interventionism,

- compulsory and free education,

- generous welfare system,

- fight against inequalities.

The Italian economist T. Boeri, on the other hand, defines ESM as (Boeri, 2002):

- labour market protection,

- limiting poverty and social (income) inequalities,

- supporting professional activity.

Rosati, in turn, identifies the four main goals of ESM as follows (Rosati, 2009):

- full employment and protection against labour market risk (protection of jobs and worker rights);

- financial support for those permanently out of the job market or unable to work for reasons such as illness, disability, or age;

- reduction of social inequalities;

- universal access to basic social services (education, healthcare, culture).

In order to achieve the above-mentioned objectives, European states have created a set of instruments. The most popular among them include (Rosati, 2009): 
- labour market regulations (minimum wages, working time and conditions, unemployment benefits);

- $\quad$ social security systems (disability benefits and pensions, other welfare benefits, e.g. family allowances);

- income redistribution policies (taxes and money transfers as part of the social security system);

- free services or services offered at a reduced price (education, healthcare, culture, leisure).

The general ESM objectives and their corresponding instruments are presented below:

Table 1. ESM's objectives and instruments

\begin{tabular}{ll}
\hline \multicolumn{1}{c}{ Objectives } & \multicolumn{1}{c}{ Instruments } \\
\hline $\begin{array}{l}\text { Employment and protection against labour market } \\
\text { risk (e.g. decreasing wages or redundancy) }\end{array}$ & Labour market regulations (e.g. labour code) \\
\hline $\begin{array}{l}\text { Ensuring an income for those unfit for work (e.g. } \\
\text { youth, the elderly, the disabled, pregnant mothers) }\end{array}$ & $\begin{array}{l}\text { Social security system (disability pensions, } \\
\text { retirement pensions, allowances) }\end{array}$ \\
\hline $\begin{array}{l}\text { Limiting social exclusion, poverty, and reducing } \\
\text { income inequalities }\end{array}$ & $\begin{array}{l}\text { Income redistribution (e.g. progressive } \\
\text { taxation, social transfers) }\end{array}$ \\
\hline Universal access to basic social services & Social service policy (e.g. free education) \\
\hline
\end{tabular}

Source: Own results based on Rosati (2009).

There is no doubt that the shared objectives of the ESM set European countries distinctly apart from others. However, alongside the commonalities, there are also substantial differences in how the ESM is implemented across Europe in practice. The disparities are related mainly to the instruments of social policy, as well as the detailed objectives and the scope of social security services (see e.g. Kisileva and Strielkowski, 2014). There are also differences with respect to the degree of state intervention in the economy, taxation levels, and labour laws.

The often-used typology of welfare states by Esping-Andersen (2010) is rather general in character and does not account for specific European conditions. For this reason, it is the typology (other classifications have been proposed as well. Wolfgang Merkel, for instance, lists the following four models of the European welfare state, i.e. the British market model, the Dutch "polder" model, the Swedish reformed welfare state model, and the French statist model) elaborated by the Belgian economist André Sapir that has gained particularly wide currency. Sapir distinguishes four major models of social policy (ESM) implemented in contemporary Europe:

- Nordic,

- Anglo-Saxon,

- Continental,

- Mediterranean.

\subsection{Features of welfare state models described by André Sapir}

The Nordic model, often referred to as the social democratic welfare state, is characterized by high levels of taxation, generous benefits, and low income disparities. Labour unions have an important role to play, but the legal protection of employment is relatively moderate. This model allows for the greatest degree of state intervention in social policy. Specialized social security covers basically all types of social risk, and its extent is not dependent on previous income or paid contributions. The Nordic-model countries boast a free 
education and healthcare system; disability benefits and pensions are available to all citizens without exception. There is a special system of allowances for large families, the disabled, and the elderly. The essence of the Nordic system lies in the assumption that it is primarily the role of the state to ensure social security; the family and the free market are deemed unable to guarantee social welfare. The model aims to provide not only the existential minimum to the poorest, but the most comprehensive assistance possible to all citizens (regardless of their income, health, and life situation); the premise is that every individual has the right to a life on a decently high level. Countries which have adopted this model include Denmark, Sweden, Finland, and the Netherlands.

The Anglo-Saxon model is distinguished by relatively low taxation levels and a social welfare system targeted at the poor and the socially excluded (e.g. the sick and the elderly). The role of labour unions is limited and income stratification relatively high. Public services are underdeveloped and citizens often have recourse to private companies offering social services on the free market, as well as to various foundations and family help. State services are only used as a last resort (Biegański, 2008). For this reason, the model bears the hallmarks of the minimal state. It is mainly implemented in Great Britain and Ireland.

The Continental model is an example of a typical welfare state harking back to the Bismarckian solutions of the 19th century. It is characterized by extensive social security services and insurances against all kinds of labour market risk, as well as high and universally available welfare benefits. The income structure is flat and the role of labour unions substantial. The labour market protection is high and its main role is to ensure the employment of people with many years of experience. Compared to the Nordic model, the state offers only modest social services. Moreover, these functions are often taken over by the so-called "third sector", i.e. private companies, foundations, and other non-governmental organizations (Biegański, 2008). The continental model is prevalent in Germany, France, but also in Belgium and Austria.

The Mediterranean model is characterized by an elaborate pension system that allows an earlier retirement than other models. It is very costly, and, consequently, the source of high public debt. Job protection is high and labour unions play an important role. The primary responsibility of the state is to protect existing employment. Labour market policy seldom takes on an active role. Apart from paying pensions, the state does not actively engage in the benefits and allowances system. Social security allowances, such as unemployment benefits or singleparent benefits, are relatively low. For this reason, an important role in this area is played by non-governmental and religious organizations (mainly the Catholic Church) and the family (Latoszek, 2007). This model is typical of Spain, Portugal, Italy, and Greece. According to some sources, some of its elements can also be found in Ireland (Biegański, 2008).

Table 2 presents the main features of each model. It should be kept in mind, however, that the typology is based on convention and significant differences can be observed even within individual systems.

It is widely accepted (Sapir, 2005) that, of all the models, the Nordic system performs the best in practice. It is both the most effective, as measured by employment level, and the most justified, as measured by the percentage of people affected by poverty. According to many analyses, the Mediterranean model performs the worst; it is not only ineffective but also unjust. The Anglo-Saxon model is described as effective, but not just, and the continental model as just, but ineffective. The latter two are treated as intermediate solutions. 
Table 2. Social policy models in Western Europe and their main features

\begin{tabular}{ccccc}
\hline & $\begin{array}{c}\text { Nordic } \\
\text { model }\end{array}$ & $\begin{array}{c}\text { Anglo-Saxon } \\
\text { model }\end{array}$ & $\begin{array}{c}\text { Continental } \\
\text { model }\end{array}$ & Mediterranean model \\
\hline $\begin{array}{c}\text { Labour market } \\
\text { Policy }\end{array}$ & Active & Diversified & Passive & Passive \\
\hline $\begin{array}{c}\text { Employment } \\
\text { protection }\end{array}$ & Moderate & Low & High & High \\
\hline Income structure & Flat & Diversified & Flat & Flat \\
\hline Social welfare & Universal & $\begin{array}{c}\text { Limited (mainly the } \\
\text { poor and the sick) }\end{array}$ & Universal & $\begin{array}{c}\text { Limited, mainly } \\
\text { retirement pensions }\end{array}$ \\
\hline $\begin{array}{c}\text { Access to social } \\
\text { services }\end{array}$ & High & Low & Rather high & Medium \\
\hline Taxation & High & Low & Medium/High & Medium \\
\hline
\end{tabular}

Source: Own results based on Rosati (2009).

\subsection{Assessment of the welfare state in EU-15 countries}

Rosati (2009) has classified the four models in terms of two important criteria: social justice and effectiveness. The results of his analysis are shown in Table 3.

Table 3. ESM's effectiveness vs. social justice

\begin{tabular}{ccc}
\hline Justice/Effectiveness & Low & High \\
\hline High & Continental countries & Nordic countries \\
\hline Low & Mediterranean countries & Anglo-Saxon countries \\
\hline
\end{tabular}

Source: Own results based on Rosati (2009).

The authors of this article attempted to verify the above hypotheses. The study analysed employment levels and the risk of poverty in each of the EU-15 countries and matched the data to relevant country groups. In order to make the emerging relationships more clear, the analysis focused not on individual year values of the indicator, which could disrupt the general trend, but on their arithmetical means. For employment, the analysis covered the 2000-2012 period, and for the poverty level, the 2004-2012 period. The poverty level analysis also took account of social transfers (Graph 1). 


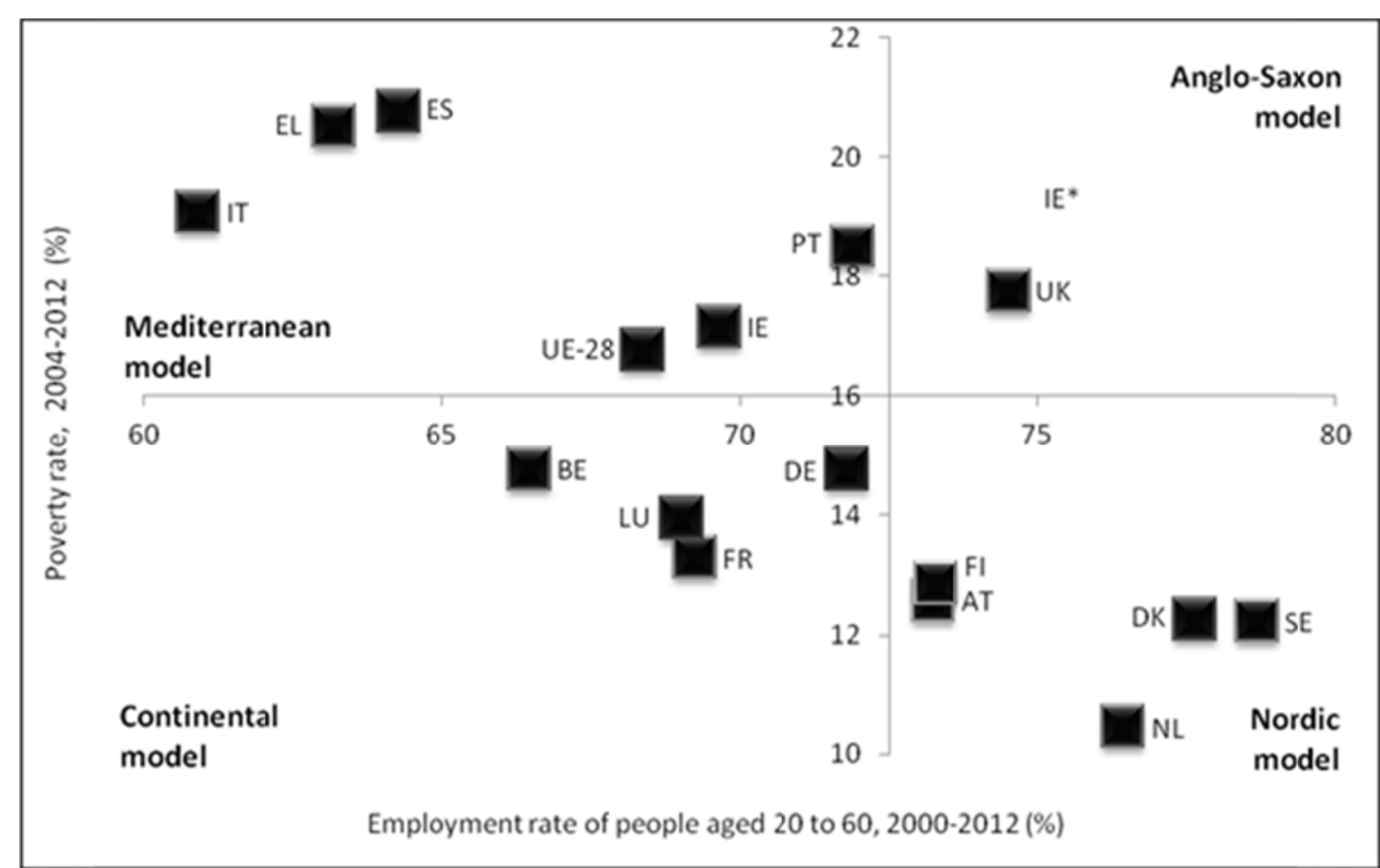

*: Ireland's placement in 2000-2007.

Graph 1. Employment and Risk of Poverty Rates, EU-15

Source: Own results based on Eurostat (2015).

The final observations are consistent with earlier assumptions. Nordic countries (the lower right-hand corner) show the best economic and social performance, while Mediterranean countries (the upper left-hand corner) perform the worst. The remaining countries (the upper right-hand and the lower left-hand corner) achieve intermediate results; at the same time, continental countries are better at ensuring social justice, while Anglo-Saxon countries lead the way in economic effectiveness. It is worth observing that not all the countries could be unequivocally matched to specific models. For Ireland, this is mainly due to the impact of the global crisis. Without the crisis, Ireland would fall within the AngloSaxon model. Austria and Portugal are also problematic; it is assumed that these two countries have partially evolved: the former in the direction of the Nordic, and the latter in the direction of the Anglo-Saxon model.

\section{Classification of Visegrád countries according to Sapir’s typology}

In the context of this article, it will be interesting to try and place the Visegrád countries within the above typology. It should be kept in mind, however, that the point of departure for the welfare state formation process was completely different in post-communist countries than in Western Europe. The former have not yet fully caught up with the rest of the continent, but the gap has been steadily shrinking.

The Visegrád countries also represent different social policies. This is due not only to cultural differences, but also to the post-communist point of departure and the specific decisions taken by leading politicians during the transformation period.

The analysis used the two indicators listed above, i.e. employment level and poverty risk. Consequently, it was possible to divide the Visegrád countries into those that show:

- a high employment rate and low poverty risk (the Nordic model);

- a low employment rate and high poverty risk (the Mediterranean model);

- a high employment rate and high poverty risk (the Anglo-Saxon model); 
- a low employment rate and low poverty risk (the Continental model).

For post-communist states, however, the division takes on slightly different values. Due to economic backwardness, economic effectiveness in these countries is lower than in the EU-15 (the vertical effectiveness line moves to the left). The poverty rate division is also less rigorous than for the EU-15 (the horizontal line moves up).

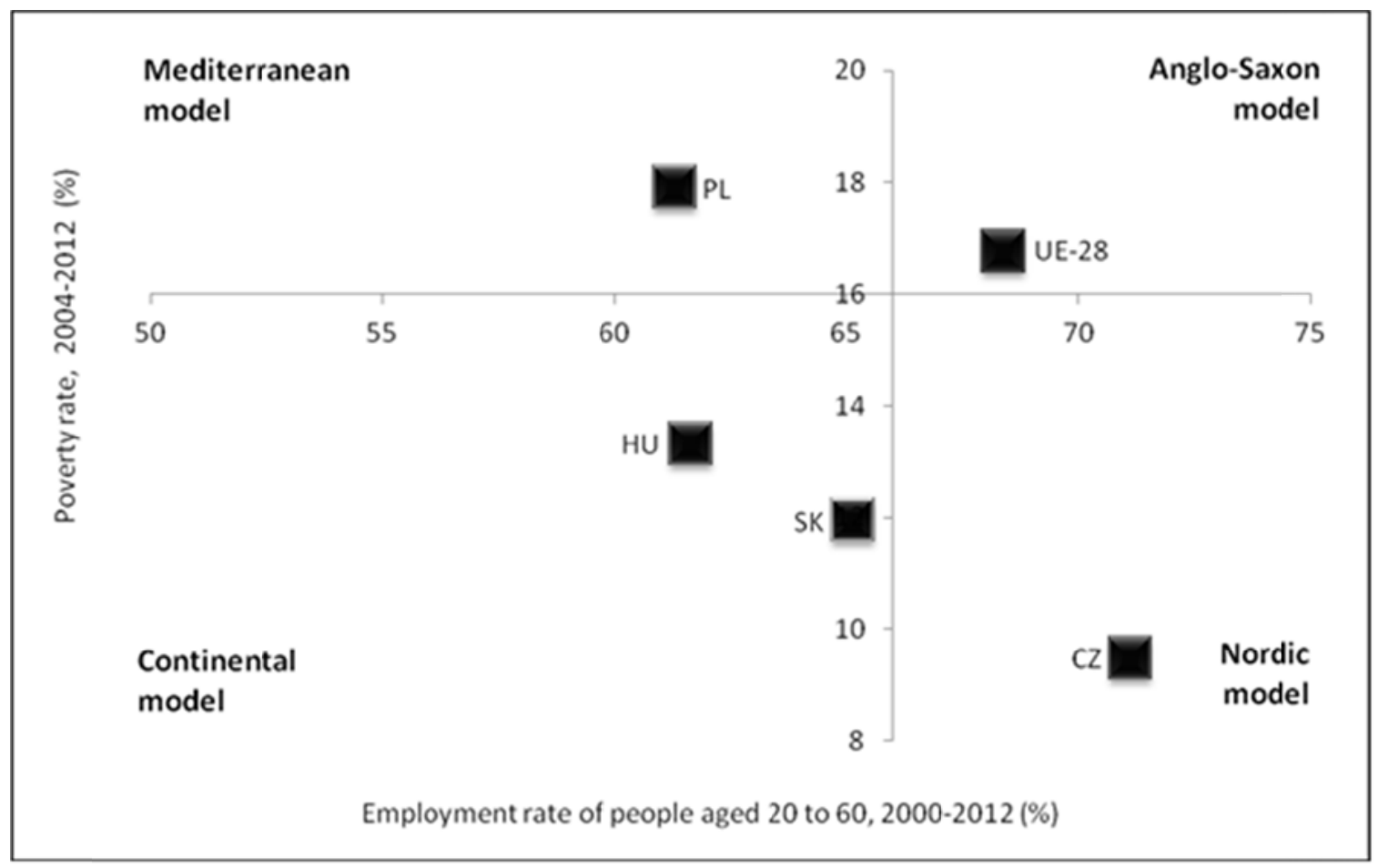

Graph 2. Employment and Risk of Poverty Rates, EU-15, Visegrad Group

Source: Own results based on Eurostat (2015).

The study shows that the Czech Republic ranks highest both in terms of effectiveness and justice. It is characterized by a low poverty rate and high employment, and therefore falls within the Nordic model. Slovakia and Hungary belong to the Continental model. They have a relatively low poverty rate but their employment level is lower than in the Nordic system. Poland shows the worst performance, ranking together with Spain, Italy, and Greece among the countries with the lowest level of economic effectiveness. For this reasion, it is included in the Mediterranean model.

\section{Assessment of the welfare state in the Visegrád countries as compared to the EU-15 based on selected indicators}

The most important index used to measure the level of economic development is the per capita GDP at purchasing power parity.

According to Eurostat data, in 2012, the index exceeded the EU average in all the old member states, except Spain, Portugal, and Greece. The Visegrád countries were significantly poorer.

When analysing the different ESM models, it is possible to observe that the per capita GDP is highest in the Nordic model countries (130-115\% of the EU average). As shown before, the continental countries are less effective and the index there stands at $123-109 \%$ of the EU average. Contrary to what was said above, however, Great Britain, the leading 
example of the Anglo-Saxon model, achieves the per capita GDP of only $95-75 \%$ of the EU average, much lower than other EU-15 countries.

The situation of the Visegrád countries seems much more instructive to examine. The Czech Republic ranks as the most developed post-communist country (81\%). The dominance of the Nordic model is even more evident in this case; the Czech Republic outranks the poorest EU-15 countries, i.e. Greece and Portugal. It is worth noting that also Slovakia (76\%, continental model) has already outpaced Greece and caught up with Portugal. Hungary and Poland, representing, respectively, the continental and the Mediterranean model, achieved the same index result ( $67 \%$ of the EU average).

The analogy between the old and the new EU countries with regard to their per capita GDP is very strong. It holds not only for the most, but also for the least developed countries.

The presented values of this indicator for separate models are comparable as well.

The study also included the HDI values, i.e. the human development index. The goal of the indicator is to neutralize the imperfections of the GDP measure, as the HDI takes into account not only the per capita GDP (at purchasing power parity) but also measures such as life expectancy and education level. Thus, it goes beyond macroeconomic data to focus on the citizens' quality of life.

As was the case with the GDP, the EU ranking is headed by the Nordic countries. The Czech Republic has significantly outpaced other Visegrád countries (as well as some of the EU15). Continental countries (especially Germany) also rank very high. This illustrates the fact that, unlike the GDP measure, where economic effectiveness is paramount, the HDI ranking also gives weight to extra-economic values, which are promoted in the continental model.

Table 4. HDI in the EU countries versus welfare state models in 2013

\begin{tabular}{ccccc}
\hline $\begin{array}{c}\text { Position in the } \\
\text { EU ranking } \\
\text { HDI }\end{array}$ & Country & $\begin{array}{c}\text { Position in the } \\
\text { world ranking HDI }\end{array}$ & Scores & $\begin{array}{c}\text { Welfare state } \\
\text { model (by Sapir) }\end{array}$ \\
\hline 1 & 2 & 3 & 4 & 5 \\
\hline 1. & Holland & 4. & 0,921 & Nordic \\
\hline 2. & Germany & 5. & 0,920 & Continental \\
\hline 3. & Sweden & 7. & 0.916 & Nordic \\
\hline 3. & Ireland & 7. & 0.916 & Anglo-saxon \\
\hline 5. & Denmark & 15. & 0.901 & Nordic \\
\hline 6. & Belgium & 17. & 0.897 & Continental \\
\hline 7. & Austria & 18. & 0.895 & Continental \\
\hline 8. & France & 20. & 0.893 & Continental \\
\hline 9. & Finland & 21. & 0.892 & Nordic \\
\hline 9. & Slovenia & 21. & 0.892 & Nordic \\
\hline 11. & Spain & 23. & 0.885 & Mediterranean \\
\hline 12. & Italy & 25. & 0.881 & Mediterranean \\
\hline 13. & Luxemburg & 26. & 0.875 & Continental \\
\hline 13. & Great Britain & 26. & 0.875 & Anglo-saxon \\
\hline 15. & Czech Republic & 28. & 0.873 & Nordic \\
\hline 16. & Greece & 29. & 0.860 & Mediterranean \\
\hline 17. & Cyprus & 31. & 0.848 & Nordic \\
\hline 18. & Malta & 32. & 0.847 & Continental \\
\hline 19. & Estonia & 33. & 0.846 & Anglo-saxon \\
\hline 20. & Slovakia & 35. & 0.840 & Continental \\
\hline 21. & Hungary & 37. & 0.831 & Continental \\
\hline 22. & Poland & 39. & 0.821 & Mediterranean \\
\hline 23. & Lithuania & 41. & 0.818 & Anglo-saxon \\
\hline & & & & \\
\hline
\end{tabular}




\begin{tabular}{ccccc}
\hline 1 & 2 & 3 & 4 & 5 \\
\hline 24. & Portugal & 43. & 0.816 & Mediterranean \\
\hline 25. & Latvia & 44. & 0.814 & Anglo-saxon \\
\hline 26. & Croatia & 47. & 0.805 & Mediterranean \\
\hline 27 & Romania & 56. & 0.786 & Mediterranean \\
\hline 28. & Bulgaria & 57. & 0.782 & Mediterranean \\
\hline
\end{tabular}

Source: Own results based on Human Development Report (2013).

However, it is impossible to conclude that the countries of any one model perform significantly better in this ranking, as was the case with the GDP measure. Alongside Nordic and continental countries, Anglo-Saxon countries, especially Ireland, also rank very high.

Another important indicator is the Gini index, which represents the degree of social stratification in a given state. The higher the index the greater the income inequalities in the country. When the index is equal to 1 (which is impossible in practice), it means that all the possible wealth in the country is owned by a single person and the rest have nothing. When it is equal to 0 (which is also impossible), everyone in the country owns the same amount of wealth.

The data show a number of relationships. The highest rate of inequality can be observed in the Anglo-Saxon and the Mediterranean model. This lends support to the earlier research that suggests they are characterized by the lowest level of social justice. Accordingly, the greatest disproportions are attested in Spain, Portugal, Greece, Great Britain, and Italy. The Gini index there is the highest.

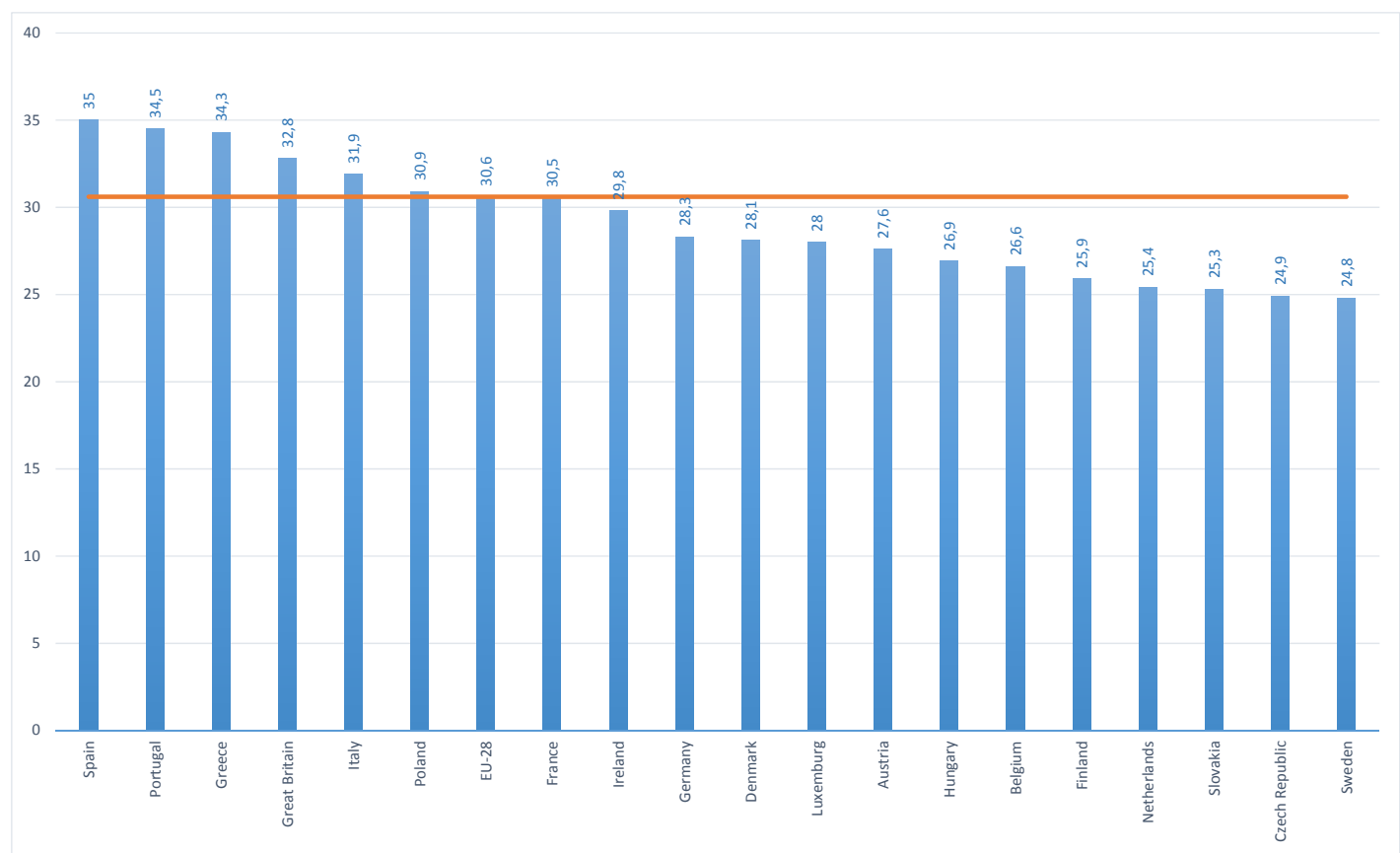

Graph 3. Gini index in the European Union countries in 2012

Source: Own results based on data from the Eurostat (2015).

The smallest disproportions are observed in the Nordic and the continental countries, which supports the earlier conclusion that they show a high level of social justice. The Gini index is lowest in Sweden, the Czech Republic, Slovakia, the Netherlands, and Finland. 


\subsection{Labour market performance}

One of the key issues in the debate about the effectiveness of the European Social Model is the performance of the labour market. Accordingly, the remaining part of the article will attempt to compare the labour market situation across the EU and examine the relationship between the level of employment and the social policy model adopted in each country.

Table 5 shows the unemployment rate across the EU member states. Between 2004 and 2013, the lowest unemployment rate was observed in Austria and the Netherlands (4.6\%), Luxembourg (4.9\%), Denmark (5.7\%), and Great Britain (6.5\%). The highest unemployment rate was attested in Spain (15.9\%), Slovakia (13.8\%), and Greece $(13.7 \%)$. It is not possible to determine which social policy model brings the best and the worst results, since both groups include countries that belong to at least two different models.

Data on the average unemployment rate among young people (under 25 years old) between 2004-2013 was also analysed. A lot of the EU countries have had a hard time keeping unemployment low in this age group. Mediterranean countries perform the worst. In Greece and Spain, the index stood at $30 \%$ in the analysed period. It was also high for Slovakia. It is worth noting that the indicator was high even in Sweden. The lowest unemployment rate in the age group was attested in the Netherlands (8.3\%), Austria (9\%) and Denmark (10.7\%).

Table 5. The average unemployment rate between 2004-2013

\begin{tabular}{cccc}
\hline Country & $\begin{array}{c}\text { The average } \\
\text { unemployment rate } \\
\left(\begin{array}{c}\% \\
\text { Austria }\end{array}\right.\end{array}$ & $\begin{array}{c}\text { The average } \\
\text { unemployment rate } \\
\text { among young people } \\
\text { under 25 years old (\%) }\end{array}$ & Welfare state model \\
\hline Holland & 4,6 & 9 & Continental \\
\hline Luxemburg & 4,6 & 8,3 & Nordic \\
\hline Denmark & 4,9 & 16,4 & Continental \\
\hline Great Britain & 5,7 & 10,7 & Anglo-saxon \\
\hline Czech Republic & 6,5 & 17 & Nordic \\
\hline Sweden & 6,8 & 16,9 & Nordic \\
\hline Finland & 7,5 & 22,4 & Continental \\
\hline Belgium & 7,9 & 19,4 & Continental \\
\hline Germany & 7,9 & 20,7 & Continental \\
\hline Italy & 8,0 & 11,1 & Continental \\
\hline Hungary & 8,3 & 26,8 & - \\
\hline France & 8,9 & 22,7 & Anglo-saxon \\
\hline EU-28 & 9,0 & 22 & Mediterranean \\
\hline Ireland & 9,0 & 19,6 & Mediterranean \\
\hline Portugal & 9,3 & 18,6 & Mediterranean \\
\hline Poland & 11,0 & 25,7 & Continental \\
\hline Greece & 11,6 & 26,9 & Mediterranean \\
\hline Slovakia & 13,7 & 34 & \\
\hline Spain & 13,8 & 29,4 & 33,7 \\
\hline
\end{tabular}

Source: Own results based on data from the Eurostat (2015). 
It can be concluded that the unemployment rate among the young is lowest in the Nordic countries and highest - in the Mediterranean countries. There are, however, certain exceptions to the rule, since the highest-ranking countries also include some continental states, while Sweden ranks relatively low.

In terms of unemployment, the Nordic welfare state model turned out to be the best. This stems mainly from the labour market policy adopted in the Nordic countries, i.e. flexicurity. The solution combines labour market flexibility (economic effectiveness) through constructing flexible forms of employment (suited to current labour market needs and the economic situation) and easy hire and fire policies with the guarantee of generous social security benefits (unemployment benefits). An important role in the model is also played by an active labour market policy targeted at unemployed citizens, e.g. skill or career transition trainings (e.g. for older people), loans for the unemployed who wish to start their own enterprise, and subsidized internships and employment opportunities for recent graduates entering the job market. These solutions have worked very well in all the Nordic model countries, and especially in Denmark.

As seen in Table 6, Denmark has devoted more than 1.5\% of its GDP to the purpose, compared to $1.3 \%$ in Belgium, and $0.8 \%$ in Finland and Sweden. These solutions have been marginal in Great Britain (0.04\%).

An important trend can be seen in the high level of spending on active job market policy in the Nordic countries of the old EU, as well as in Belgium, Ireland, and Spain, even though in the latter two, its share in general labour market policy spending is much lower.

Table 6. Expenditure on labour market in the EU countries in 2011

\begin{tabular}{ccccc}
\hline Country & $\begin{array}{c}\text { Labour market } \\
\text { services }\end{array}$ & $\begin{array}{c}\text { Active job market } \\
\text { policy }\end{array}$ & $\begin{array}{c}\text { Passive job market } \\
\text { policy }\end{array}$ & Total \\
\hline Denmark & 0,543 & 1,541 & 1,646 & 3,73 \\
\hline Belgium & 0,212 & 1,379 & 2,091 & 3,682 \\
\hline Finland & 0,124 & 0,857 & 1,475 & 2,456 \\
\hline Sweden & 0,248 & 0,805 & 0,631 & 1,684 \\
\hline Ireland & 0,137 & 0,714 & 2,64 & 3,491 \\
\hline Spain & 0,106 & 0,708 & 2,881 & 3,695 \\
\hline Holland & 0,373 & 0,7 & 1,641 & 2,714 \\
\hline France & 0,252 & 0,682 & 1,402 & 2,336 \\
\hline Austria & 0,186 & 0,571 & 1,286 & 2,043 \\
\hline Luxemburg & 0,053 & 0,459 & 0,638 & 1,15 \\
\hline Portugal & 0,116 & 0,458 & 1,336 & 1,91 \\
\hline Germany & 0,34 & 0,446 & 1,022 & 1,808 \\
\hline Hungary & 0,01 & 0,35 & 0,662 & 1,022 \\
\hline Poland & 0,084 & 0,333 & 0,304 & 0,721 \\
\hline Italy & 0,032 & 0,307 & 1,365 & 1,704 \\
\hline Greece & 0,011 & 0,224 & 0,726 & 0,961 \\
\hline Slovakia & 0,072 & 0,223 & 0,496 & 0,791 \\
\hline Czech Republic & 0,097 & 0,178 & 0,281 & 0,556 \\
\hline Great Britain & 0,341 & 0,04 & 0,303 & 0,684 \\
\hline
\end{tabular}

Source: Own results based on data from the Eurostat (2015).

A general conclusion can be drawn that the active job market policy used in the Nordic countries is much more effective than passive policy, as it effectively reduces unemployment and has a positive impact on employment rate. This is one of the factors which 
explain the good performance of Nordic labour markets. On the other hand, it must be noted that this is not a universally valid rule (Tendera-Właszczuk, 2010).

In 2013, the employment rate in Belgium was lower by $7 \%$ than in Great Britain, even though the country spent approximately 20 times more of its resources on active employment policy.

\subsection{Public spending and the reduction of poverty}

Another important issue that awaits our attention is the level of public spending in the EU countries. Countries, where public spending accounts for the highest percentage of the GDP, include the EU-15 (especially those that belong to the Nordic and the Continental models). The average public spending in Denmark between 2008 and 2012 accounted for $57 \%$ of the GDP and was the highest in the entire European Union. Other countries with high public spending include: France (56\%), Finland (55\%), Belgium and Sweden (53\% each). The lowest budget spending was attested in Slovakia (39\%). When data from before the crisis (i.e. the 2002-2007 average) is considered, however, the lowest values are observed for the Anglo-Saxon model, and particularly Ireland (34\% of the GDP).

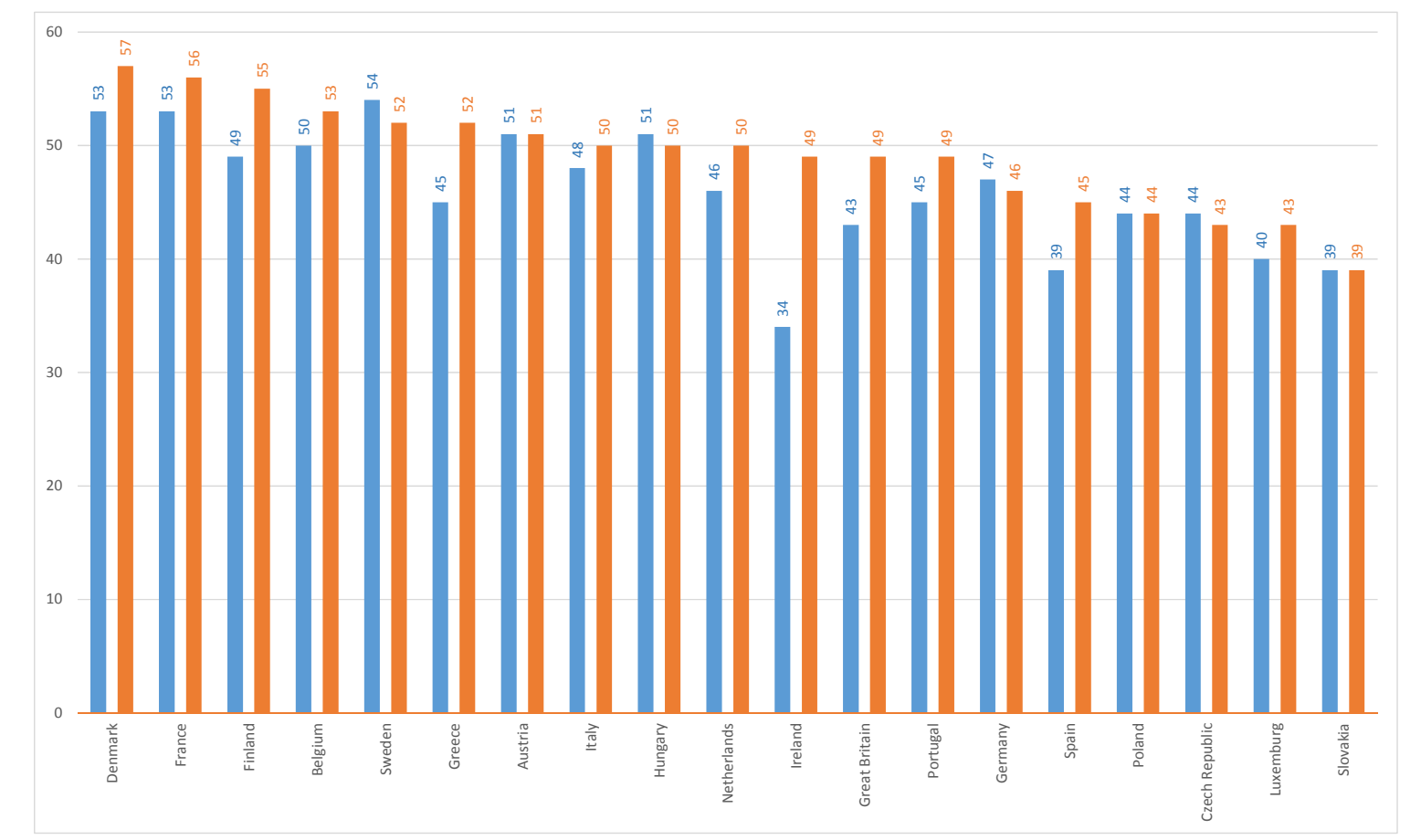

Graph 4. Public spending in the EU countries (average level for 2002 - 2007 and 2008 - 2012 as $\%$ of GDP

Source: Own results based on data from the Eurostat (2015).

Another important issue of public spending analysis is the share of social expenses in the GDP (Graph 5). Just as above, the greatest spending (in terms of the 2008-2011 average) was recorded in the Nordic countries - Denmark (34\% of the GDP), the Netherlands (31\%), and Sweden (30\%), as well as the continental countries, such as France, Germany, Belgium, and Austria (more than 30\%). The Visegrád countries devoted a much lower share of their GDP to these purposes. 


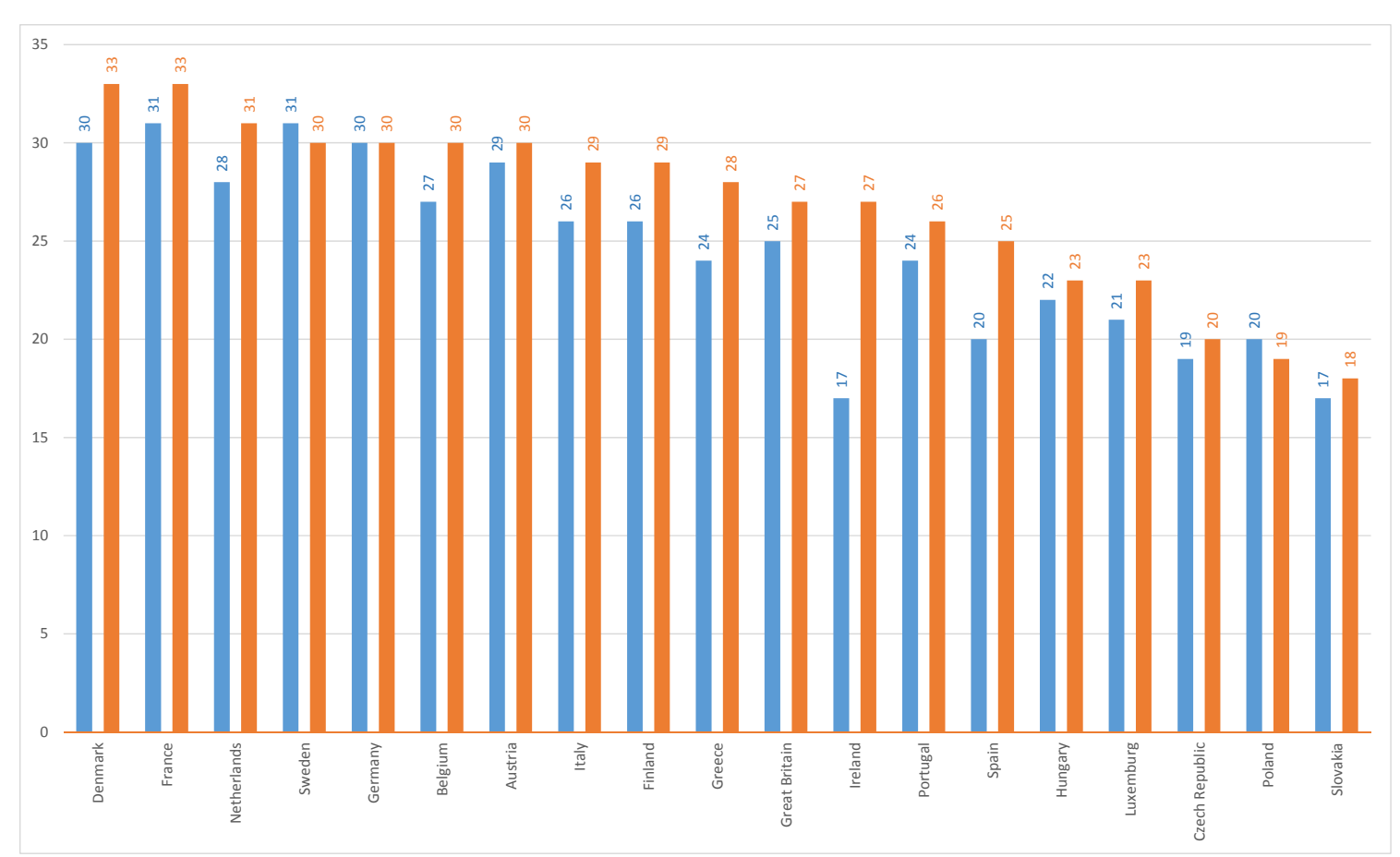

Graph 5. Public spending on social expenses in the EU countries (average level for 2002 2007 and $2008-2012$ as \% of GDP)

Source: Own results based on data from the Eurostat (2015).

Graph 6 shows the relationship between public spending and the HDI. In the analysed group, a moderate positive correlation $(\mathrm{R}=0.6224)$ was observed between the two variables; the coefficient of determination was $\mathrm{R}^{2}=0.3874$. This shows that, to a certain extent, the HDI is determined by the level of public spending - the greater the expenditures, the higher the human development index.

However, it should be noted that even though Ireland and Sweden are similar in terms of the human development level measured by the HDI, their public spending policies differ greatly. In recent years (1995-2012), public spending in Ireland accounted, on average, for only $39 \%$ of the GDP (if not for the crisis, Irish public spending would be even lower and the HDI even higher.), as compared to more than 55\% in Sweden, which suggests that the extra spending in Sweden (a difference of more than 15\%) does not produce desired results. 


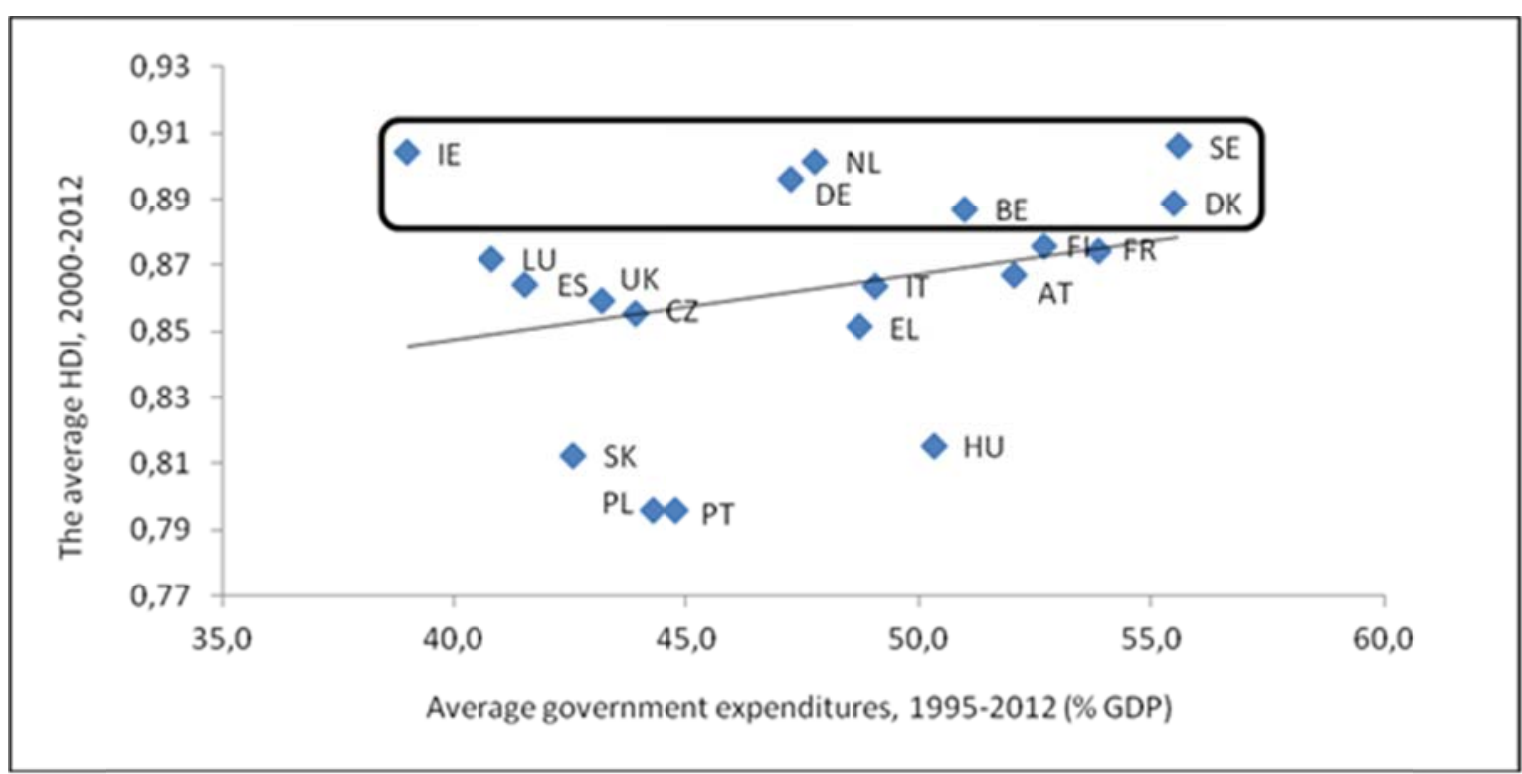

$$
R=0,6224 \quad R^{2}=0,3874 \quad y=0,0049 x+0,6231
$$

Graph 6. Government Expenditure to Quality of Life, EU-15 and Visegrad Group Source: Own results based on data from the Eurostat (2015).

More evidence for the diminishing utility of public spending is provided in Table 7, which presents changes in the level of public spending and the HDI. Because of the limited access to historical information, we could only present data for some years.

Table7. Public spending and the HDI

\begin{tabular}{ccccccc}
\hline \multirow{2}{*}{ Country } & \multicolumn{3}{c}{ Public spending (\%GDP) } & & HDI & \\
\cline { 2 - 7 } & 1983 & 1990 & 2007 & 1980 & 1990 & 2007 \\
\hline Belgium & 64 & 53,8 & 48,2 & 0,764 & 0,817 & 0,891 \\
\hline Holland & 59.3 & 54,9 & 45,3 & 0,799 & 0,793 & 0,911 \\
\hline Country & 1993 & 2005 & 2007 & 1990 & 2005 & 2007 \\
\hline Finland & 64,9 & 50,3 & 47,4 & 0,801 & 0,882 & 0,89 \\
\hline Slovakia & 78,8 & 38 & 34,2 & 0,754 & 0,814 & 0,83 \\
\hline
\end{tabular}

Source: Own results based on data from the Eurostat (2015).

The table shows that in a number of instances, a decrease in public spending not only did not compromise the quality of life, but even improved it. For example, in Belgium, public spending has decreased by almost $15 \%$ over the last 30 years, while the HDI in the same period has increased significantly. A similar relationship could be observed for the Netherlands, Finland, and Slovakia, the new EU country.

Graph 7 presents even more evidence that public spending can be managed both justly and effectively. 


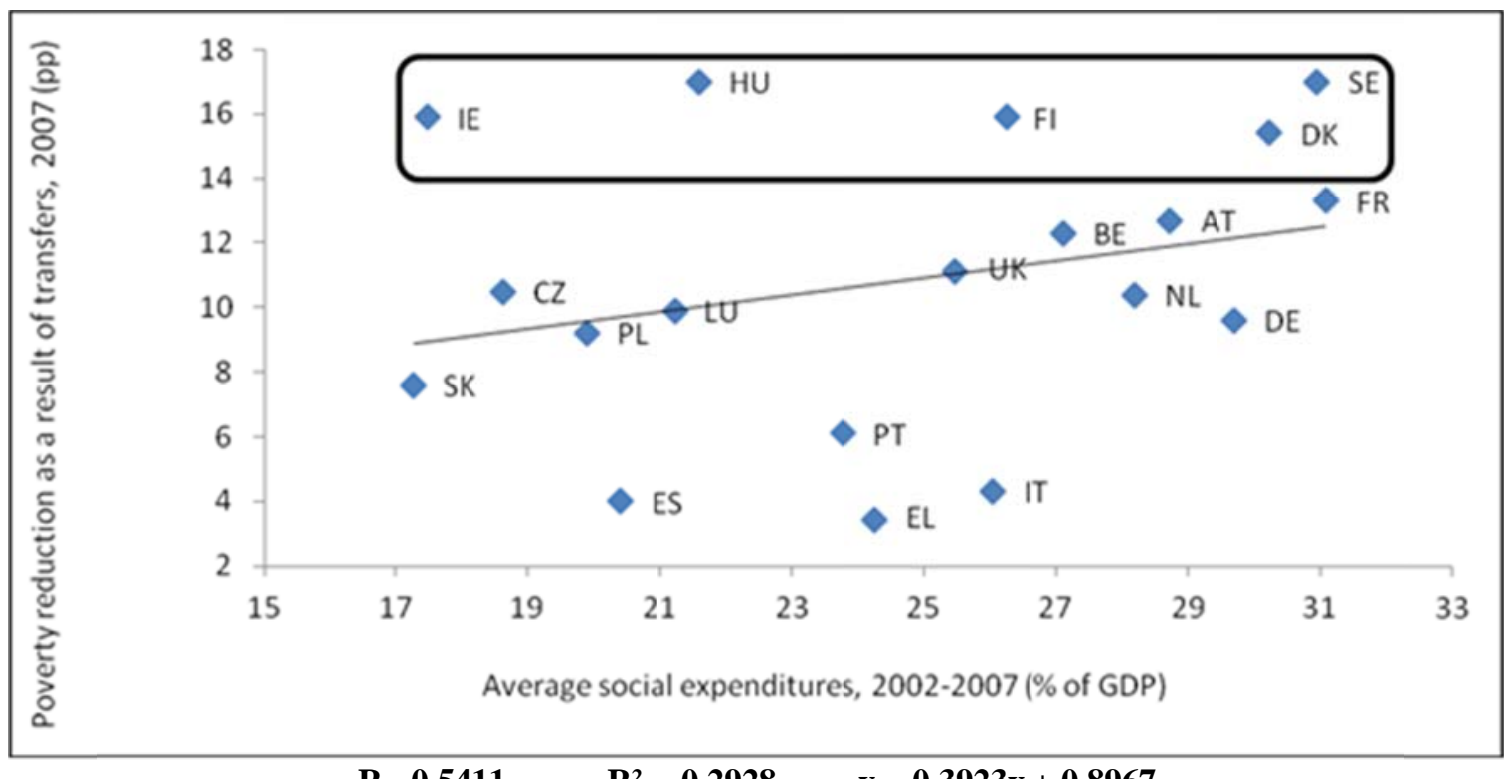

Graph 7. Effectiveness of social expenditures to reduce poverty, EU-15 and Visegrad Group Source: Own results based on data from the Eurostat (2015).

There exists a moderate positive correlation between the amount of social spending and the reduction of poverty $\mathrm{R}=0.5411$, with the coefficient of determination of $\mathrm{R}^{2}=0.2928$, which means that the countries which spend more reduce poverty to a greater extent than those which spend less. The linear regression function demonstrates that with each $1 \%$ increase in public spending poverty rates drop by an average of $0.39 \%$.

It should be noted, however, that it is possible to reduce poverty by as much as the Nordic countries with much less spending in the public sector. A case in point, for instance, is Ireland, which only spent an average of $17 \%$ of its GDP on social purposes between 20022007, and still recorded a poverty reduction rate of 16\%. Similar results (approx. 17\%) were only attested in the Nordic countries, where the average public spending level stood at $30 \%$ of the GDP.

Therefore, despite the moderate positive correlation, it is still possible to reduce poverty with a relatively low level of public expenditure. This confirms the law of diminishing returns with regard to the public sector. Slovakia is a good case in point.

\section{Conclusions}

The analysis shows that the Nordic system performs the best among all the welfare state models in terms of the principal assessment criteria that include the labour market situation, as well as the reduction of poverty and social inequalities. However, the Nordic social policy model, based on the assumption that the state is designed not only to preserve but also to expand the welfare of its citizens, though widely admired, is not without its flaws.

In theory, the Nordic countries have been successful in reducing poverty. However, their policies have not been very cost-effective; public spending exceeds $30 \%$ of the GDP, and the global crisis has increased it even further. The example of Anglo-Saxon Ireland shows that public expenditure can be used more effectively to fight poverty; Ireland has managed to reduce poverty by almost as much as Sweden, Finland, or Denmark, but at a much lower cost.

In the analysis, the Visegrád countries, and the Czech Republic (the Nordic model) and Slovakia (the continental model) in particular, achieve satisfactory results across all indicators. 
The current situation is different. Recent data suggest that the global crisis has caused an increase in the level of poverty and social spending in Ireland. However, this is just a temporary situation and it does reflect the solutions of the Anglo-Saxon model.

Assuming that all citizens are eligible to receive the benefits of the welfare state, it is extremely difficult to keep public spending at a prudent level. It is recommended that the number of eligible citizens should be reduced. This would no doubt fundamentally change the system, but also allow for a better allocation of capital without compromising the effectiveness of social welfare.

It is true that the baseline poverty level (before social transfers) in the Nordic model is lower than in Ireland and that even the high effectiveness of Anglo-Saxon solutions will not succeed in bringing poverty down to a level lower than, for instance, that of Denmark. It is, however, highly probable that at least a partial approximation to the Anglo-Saxon model could give a boost to economic recovery, and lower taxation would help create new jobs, thus enabling an effective reduction of poverty.

\section{References}

Auleytner, J., Głąbicka, K. (2000), Polityka społeczna, pomiędzy opiekuńczościq a pomocniczościa, wyd. Wyższa Szkoła Pedagogiczna w Warszawie, Warszawa.

Biegański, Z., Jackowicz, J. (2008), Unia Europejska - społeczne i gospodarcze aspekty integracji, wyd. Wyższa Szkoła Pedagogiczna w Warszawie, Warszaw.

Borowiec, J. (2011), Ekonomia integracji europejskiej, wyd. Uniwersytet Ekonomiczny we Wrocławiu, Wrocław.

Buchanan, J. M., Musgrave, R. A. (2005), Finanse publiczne a wybór publiczny. Dwie odmienne wizje państwa, Wydawnictwo Sejmowe, Warszawa.

Č́belková, I., Strielkowski, W. (2013), Is the level of taxation a product of culture? A cultural economics approach, Society and Economy, Vol. 35, Issue 4, pp. 513-529. DOI: http://dx.doi.org/10.1556/SocEc.2013.0007

Dośpiał-Barysiak, K. (2007), Państwa nordyckie a Unia Europejska, Wydawnictwo Sejmowe, Warszawa.

Esping-Andersen, G. (2010), Trzy światy kapitalistycznego państwa dobrobytu, wyd. Difin, Warszawa.

Eurostat (2011), Labour market Policy - Expenditure and Participants, Data 2011, Retrieved from: http://epp.eurostat.ec.europa.eu.

Eurostat (2015), Statistics, Retrieved from: http://epp.eurostat.ec.europa.eu.

Firlit-Fesnak, G., Szylko-Skoczny, M. (2008) (red.), Polityka społeczna, PWN, Warszawa.

Głąbicka, K.(2010), Prekursorzy socjalnego wymiaru Europy, wyd. Politechnika Radomska, Radom.

Grewiński, M., Malinowski, K. (1999), Europejski Fundusz Socjalny i rynek pracy w Unii Europejskiej, Dom Wydawniczy Elipsa, Warszawa.

Hill, M. (2010), Polityka społeczna we współczesnym świecie - analiza porównawcza, wyd. Difin, Warszawa.

Human Development Report 2013.

Jodkowska, L. (2009), Państwo opiekuńcze w Polsce $i$ w Niemczech, wyd. Difin, Warszawa.

Kiseleva, L. S., Strielkowski, W. (2014), Economic analysis of happiness, wellbeing and health: a Tyumen region case study, Actual Problems in Economics, Vol. 11, Issue 161, pp. 245-254.

Latoszek, E. (2007), Integracja Europejska. Mechanizmy i wyzwania, wyd. Książka i Wiedza, Warszawa. 
Rosati, D. K. (2009) (red.), Europejski model społeczny, doświadczenia i przyszłość, Polskie Wydawnictwo Ekonomiczne, Warszawa.

Strielkowski, W., Čábelková, I. (2015), Religion, Culture, and Tax Evasion: Evidence from the Czech Republic, Religions, Vol. 6, Issue 2, pp. 657-669. DOI: http://dx.doi.org/10.3390/rel6020657.

Strielkowski, W., Hejlová, D., Kisileva, L. (2014), Economic factors influencing wellbeing and the quality of life, Journal of Applied Economic Sciences, Vol. IX, Issue 3(29), pp. 488-494.

Tendera-Właszczuk, H. (2010) (red.), Polityka społeczna Unii Europejskiej po wschodnim rozszerzeniu, Polskie Towarzystwo Ekonomiczne, Kraków. 